\title{
Tysk nazistisk ungdomsarbejde i Nordslesvig 1933-1945
}

\author{
Deutsche Jungenschaft Nordschleswig \\ Deutsche Mädchenschaft Nordschleswig
}

\section{af Nina Jacobsen}

I 1993 udskrev Historisk Samfund en prisopgave om et selvvalgt emne i Nordslesvigs historie efter 1920. Blandt besvarelserne var et manuskript om tysk ungdomsarbejde i Nordslesvig 1933-1945 udarbejdet af cand. mag. Nina Jacobsen, Kebenhavn. Nedenstående er en bearbejdet og forkortet udgave af manuskriptet, som tillige var forfatterens specialeafhandling i tysk ved Københavns Universitet.

\section{Indledning}

Hvor mange mennesker ved, at der eksisterede Hitler-Jugend-organisationer i Danmark? Hitler-Jugend var den organisation, som overførte det nazistiske tankegods til den tyske ungdom. Hitler-Jugend og den tilsvarende pigeorganisation Bund Deutscher Mädel havde til opgave at opdrage de tyske drenge og piger til trofaste og lydige tilhængere af nazismen. For drengenes vedkommende stod soldatertjenesten som det store forbillede, mens det for pigerne var opfyldelsen af modergerningen, der stod $i$ centrum.

I Nordslesvig var der inden for det tyske mindretal to ungdomsorganisationer, der svarede til disse forbilleder i Nazi-Tyskland. Blot havde de ikke de samme betegnelser som de tyske forbilleder. Drengeorganisationen hed Deutsche Jungenschaft Nordschleswig, pigernes organisation bar navnet Deutsche Mädchenschaft Nordschleswig. Men indholdet og organisationsstrukturen var den samme som i de rigstyske organisationer - eller var den?

Denne artikel vil belyse, $i$ hvilken grad de to nordslesvigske organisationer Jungenschaft og Mädchenschaft lignede deres forbilleder syd for grænsen. Var der tale om en simpel efterligning, eller havde de et særligt tysk-nordslesvigsk særpræg? Udover belysningen af dette spørgsmål vil ensretningen af det tyske ungdomsarbejde i Nordslesvig blive behandlet.

Til belysning af de to ungdomsorganisationers arbejde findes der på Landsarkivet for Sønderjylland en del materiale såsom "skolingsbreve«, tryksager, indberetninger fra møder og træf osv. Dog mangler der vigtige ting, bl.a. førerkartoteker fra de enkelte kredse og referater fra »landsungdomsledelsen «, som var det øverste organ for DJN og DMN. Udover det utrykte materiale fra 
Jungen- og Mädchenschaft findes der også to tidsskrifter, som blev udgivet af den tyske ungdom i Nordslesvig, nemlig Junge Front og Junger Wille. Sidstnævnte udkom som bilag til det større Junge Front, og det var det egentlige medlemsblad for Jungenschaft og Mädchenschaft.

Som supplement til det skriftlige kildemateriale har jeg interviewet den tidligere fører for Jungenschaft Jef Blume samt tidligere medlemmer af hhv. Jungen- og Mädchenschaft.

\section{Tysk ungdomsarbejde før 1933}

Med folkeafstemningen i 1920 befandt den tysksindede befolkning i Nordslesvig sig i en helt ny situation. De tysksindede var nu en minoritet inden for det danske samfund og måtte derfor omstrukturere og reorganisere sig som sådan. De tysksindede, som traditionelt var organiseret før 1920, var typisk embedsmænd og tilflyttede intellektuelle fra Tyskland. Den brede tysksindede befolkning i Nordslesvig, bl.a. bønder og selvstændige, havde i hovedregelen kun markeret sig ved de store mærkesager, såsom ved folkeafstemningen. Egentlig organisatorisk aktivitet var der mangel på.

Med dannelsen af Schleswigscher Wählerverein i 1920 kom der skub i tingene. Som led $\mathrm{i}$ ønsket om en kulturel autonomi oprettedes en tysk skoleforening, Deutscher Schulverein für Nordschleswig, der skulle varetage oprettelsen af tyske skoler. Netop de tyske skoler blev det vigtigste punkt på den kulturelle autonomi-dagsorden.

Ungdomsarbejdet fik ligeledes høj prioritet i ledelsen, fordi man hurtigt indså, at en forbedring af den tysksindede ungdoms vilkår ville knytte den tættere til mindretallet og forhindre de unge $i$ at melde sig ind i danske ungdomsforeninger. Ungdomsarbejdet blev følgelig en vigtig del af den kulturelle kamp i det dansk-tyske grænseområde.

Målgruppen var primært de unge, der havde forladt skolen. Denne gruppe blev anset for at være særlig udsat for dansk påvirkning, fordi de var for unge til at blive medlem af mindretallets foreninger. Der eksisterede kun enkelte ungdomsforeninger fra tiden før grænsedragningen (Wandervogel og spejdere). Situationen var altså den, at det gjaldt om at opbygge et ungdomsarbejde fra grunden.

Dette skete da også hurtigt: I 1921 oprettedes "Deutscher Jugendbund Nordschleswig«, senere ændret til »Deutscher Jugendverband Nordschleswig". Formand blev mindretallets ledende skikkelse pastor Johannes Schmidt, og sekretær og forretningsfører blev Reinhold Hesse. Ungdomsforbundene følte sig åndeligt som en del af den tyske forbundsungdom »Die bündische Jugend«. For- 


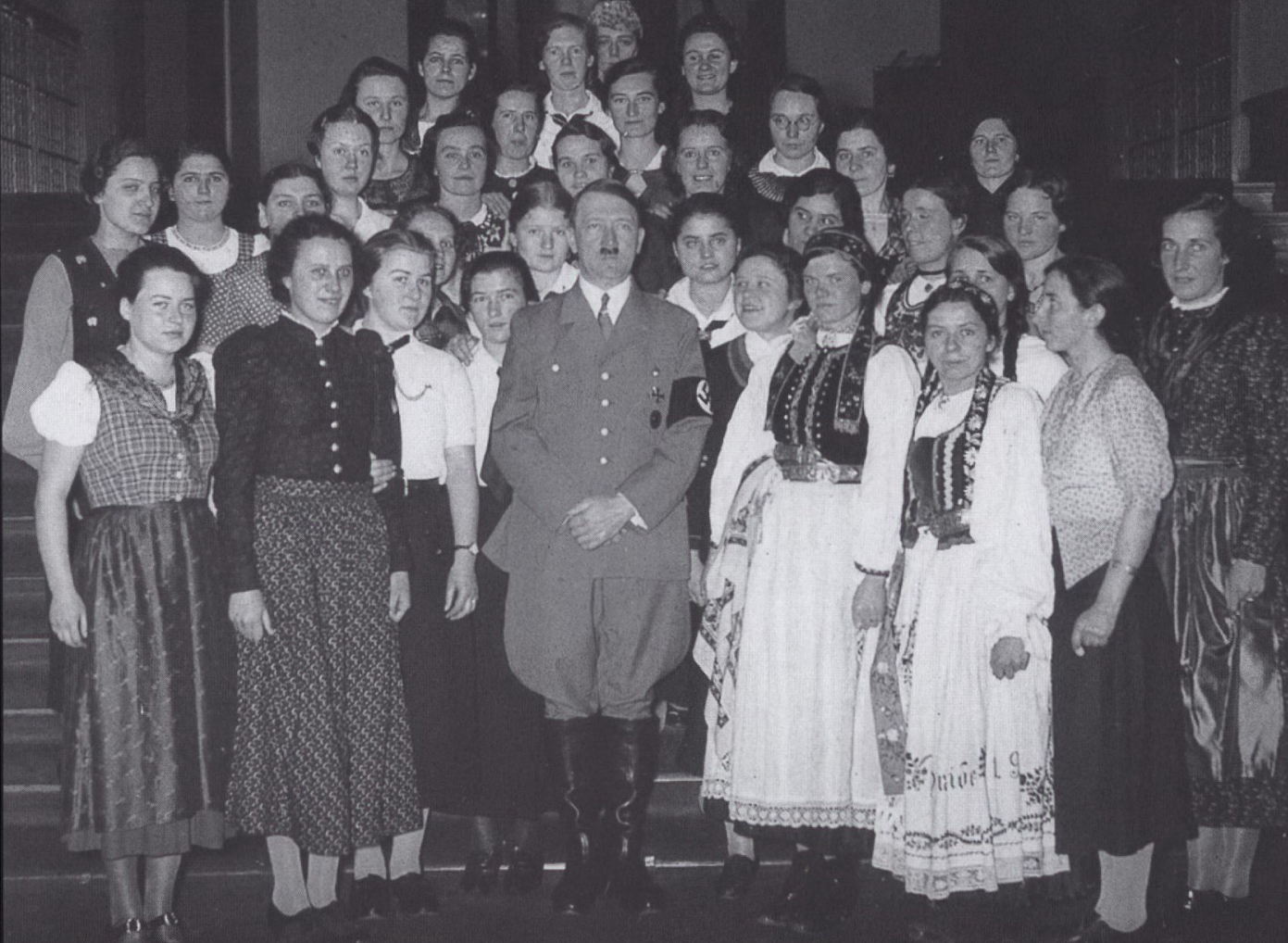

I 1937-38 besogte folketyske pigeledere, herunder Mädchenschaftlerne fra Nordslesvig, foreren i Berlin. De nordslesvigske Mädchenschaftler har almindelig Mädchenschafts-uniform pd, dvs. mork nederdel. hvid skjorte og torklode. Privateje.

bundsungdommen var en borgerlig ungdomsbevægelse, hvor bl.a. det frie liv i naturen, ungdommen som særskilt livsstadie og unges »selvopdragelse« blev sat $\mathrm{i}$ fokus. Repræsentanter for bündische Jugend var bl.a. Wandervogel-bevægelsen.

Det overordnede mål for ungdomsforbundene blev, at alt arbejde skulle sættes ind på at værne og uddybe tysk sæd og skik. Man betragtede sig selv som bærere af tysk liv og ære over for det danske folk. ${ }^{1}$ I praksis blev det tyske liv dyrket gennem foredrag, oplæsninger, sang, folkedans, koraftener og idræt. Ungdomsforbundene var ikke kønsopdelt.

Tilslutningen viste, at satsningen på ungdomsarbejde udfyldte et tomrum: I 1922 var der således 29 ungdomsforbund med lidt over 2.000 medlemmer. Herefter faldt antallet betydeligt: I 1928 var der i alt 31 lokale afdelinger med i alt 1.481 medlemmer. I 1932 var tallet nået op på 1.700 medlemmer og lokalafdelingerne op på $42 .^{2}$

Udover ungdomsforbundene fandtes der Wandervogel og spejderforeninger, der ikke talmæssigt var af stor betydning. Dertil kom unge fra idrætsforeninger og roklubber. Efter 1920 oprettede man ligeledes vandrehjem for unge. For- 


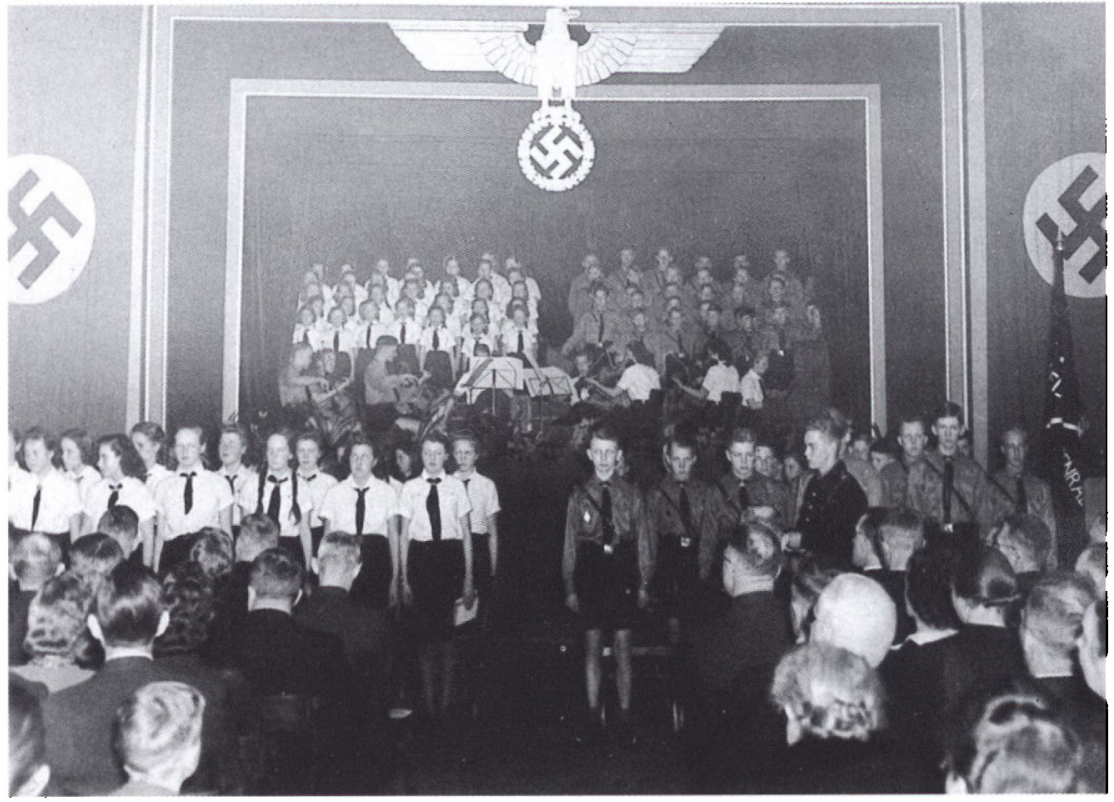

Nazistisk kunfirmation i Aabenraa 1944. Fra 1939 indfortes den nazistiske konfirmation, kaldet "Verpfichtung der Jugend", hvori de 14-arige skulle svarge troskab til forer og fane. Hos Hitler-Jugend markerede denne Verpflichtung en overgang til det egentlige Hitler-Jugend, men i mindretallet fandtes denne formelle skelnen ikke. Dette og de folgende billeder stammer fra Institut for sonderjysk lokalhistorie i Aabenraa.

målet var dobbelt: Dels at vandre - det var en vigtig del af forbundsungdommens idégrundlag, (man talte om ungdomsvandring som en helbredende eller forebyggende foranstaltning over for tuberkulose, kønssygdomme (!), alkohol og andre kropslige nedbrydelser ${ }^{3}$ ), og dels var vandrehjemmene et vigtigt bindeled mellem tysk ungdom i Nordslesvig og tysk ungdom i Slesvig-Holsten. I 1925 oprettedes en særlig nordslesvigsk afdeling af »Reichsverband für deutsche Jugendherbergen«, som i 1935 blev til et selvstændigt forbund kaldet "Deutsches Jugendherbergswerk Nordschleswig."

Ved Hitlers magtovertagelse 30. januar 1933 var man kommet så vidt, at der eksisterede et velfungerende ungdomsarbejde med lokale afdelinger og med lokalt selvstyre overalt i Nordslesvig.

\section{Ensretningen af det tysk-nordslesvigske ungdomsarbejde}

Inden jeg behandler ensretningen af ungdomsorganisationerne, er det på sin plads at definere begrebet »ensretning « eller »nazificering«, »Gleichschaltung«, 
som det hedder på tysk, er et begreb, der stammer fra nazisterne selv. Det blev brugt om de ideologiske og organisatoriske forholdsregler, som Hitler iværksatte fra 1. april 1933. ${ }^{4}$ Formålet var at indordne organisationer og institutioner af politisk, samfundsmæssig og økonomisk karakter under det nazistiske parti. Dette skete enten ved at give organisationerne et nyt indhold eller ved helt at forbyde dem og samtidig danne nazistiske organisationer, hvis arbejdsområde svarede til de tidligere opløste organisationers.

I Nordslesvig kunne man i sagens natur ikke gå frem helt på samme måde. Først og fremmest var der ikke et nazistisk parti ved magten i Danmark, som kunne gribe ind på tilsvarende diktatorisk vis. Dertil kom, at der ikke eksisterede et tysksindet nazistparti før Hitlers magtovertagelse. Denne "mangel" blev der dog hurtigt rådet bod på, selvom spørgsmålet om hvem, der skulle lede det tysksindede nazistparti i Nordslesvig blev genstand for langvarige stridigheder. Først fra 1935 blev der enighed om at gøre dyrlægen Jens Møller fra Gråsten til leder af »Nationalsozialistische Deutsche Arbeiter-Partei Nordschleswig" som det samlende parti. Uroen fortsatte dog helt frem til 1938.

Ensretningen af ungdomsorganisationerne i Nordslesvig foregik stort set på samme måde som i Tyskland, men hvor der i Tyskland var tvang, øvede man i Nordslesvig pres. Først og fremmest oprettede man de to nazistiske ungdomsorganisationer, Deutsche Jungenschaft Nordschleswig (DJN) og Deutsche Mädchenschaft Nordschleswig (DMN), som efterhånden blev de altdominerende inden for tysk ungdomsarbejde. Dernæst blev de eksisterende ungdomsforbund tilført nazistisk indhold og underlagt nazistisk overherredømme for tilsidst at forsvinde.

Udviklingen inden for ungdomsforbundene mellem 1933 og 1937 kan bl.a. forfølges i Deutscher Volkskalender Nordschleswig og i en korrespondance, som findes bevaret i Jungenschafts arkiv i Landsarkivet i Aabenraa. Denne korrespondance giver et godt indblik i de komplikationer, der opstod i forbindelse med nazificeringen af ungdomsorganisationerne. Modsætningerne bar både præg af personlige uoverensstemmelser og reel uenighed om den nye linje inden for ungdomsarbejdet.

Mellem 1934 og 1935 indstillede ungdomsforbundene så godt som fuldstændigt deres foreningsarbejde for at afvente den nye udvikling $i$ syd. Udviklingen for året 1933/34 kan aflæses udfra forretningføreren Reinhold Hesses beretning i Volkskalender fra 1935. Principielt var holdningen den, at man sluttede op omkring nazismen, men at man endnu ikke vidste, hvordan et nazistisk ungdomsarbejde skulle tage sig ud i Nordslesvig (mikke afklaret, hvordan man bedst kunne tjene til udbredelsen af den nazistiske idé (). ${ }^{5}$

Ungdomsforbundene fortsatte dog arbejdet med deres hjertebarn, den tysk- 


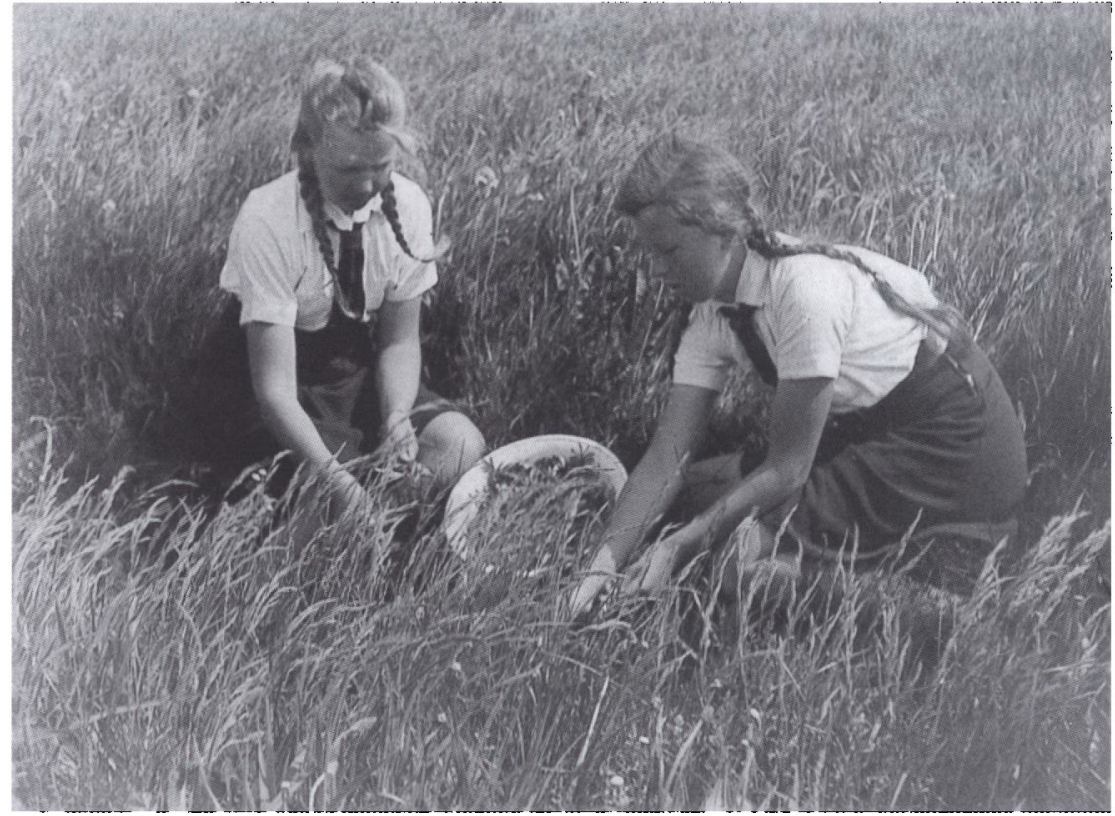

Indsamling af lageurter i D.M.N. 1943. Hvor soldaten var idealet for drengene, var moderen idealet for pigerne. Derfor blev pigernes opdragelse lagt an på at tilegne sig huslige fardigheder, sásom at fore en husholdning, madlavning og håndarbejde. Dertil horte ogsd kendskab til naturens planter.

sindede landsbyungdom. Indstillingen af det daglige foreningsárbejde fik hurtigt konsekvenser: På tre år, fra 1933 til 1935, faldt medlemstallet med 900 medlemmer, hvilket betød en halvering af ungdomsforbundene.

Men kunne ungdomsforbundene fortsætte med at eksistere uden at blive en del af det nazistiske system? Reelt synes det ikke at have været nogen mulighed, i hvert fald var den svær at gennemfore: Ungdomsforbundene var åndeligt og økonomisk tæt knyttet til Tyskland: Åndeligt, idet man forstod sig selv som en del af Tyskland, - og dermed følte en forpligtelse til at følge moderlandet ideologisk - og økonomisk, idet man fik støtte fra tyske foreninger som f.eks. "Verein für das Deutschtum im Ausland « og fra slesvig-holstenske foreninger. Dette medførte, at det tyske ungdomsarbejde i Nordslesvig på kortere eller længere sigt måtte nazificeres. Og til dette formål oprettedes i 1935 den såkaldte »Jugendring

\section{Oprettelsen af Jugendring}

"Deutscher Jugendring Nordschleswig« blev oprettet i efteråret 1935 med det formål at koordinere det tyske ungdomsarbejde i Nordslesvig. Ungdomsringen 


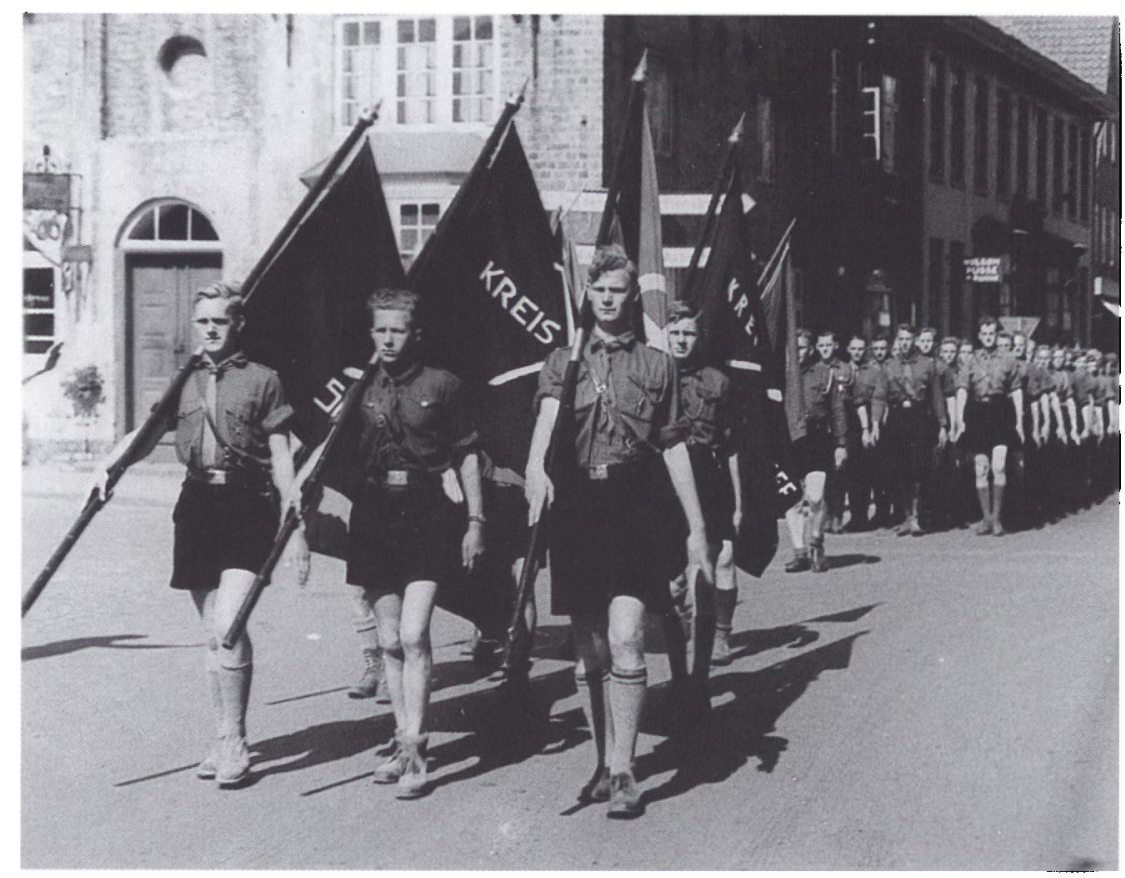

Jungenschaftler marcherer gennem Tonder. For Jungenschaft (og Mädchenschaft) var marcher en vigtig del af deres virke. Ved disse marcher blev den rette militare disciplin og holdning tranet, samtidig med at man manifesterede sig over for den dansksindede befolkningsdel. I 1939 var det officielt stadigvak forbudt for politiske organisationer at optrade i uniform. Fra dansk side händhavede man dog ikke forbudet under besattelsen, idet det muligvis kunne skade forholdet til Tyskland.

var tænkt som en midlertidig organisation. På lang sigt skulle hele den tyske ungdom, dvs. ungdomsforbundene, vandrehjemsarbejdet og de unge fra sportsforeningerne, sammenfattes i sammenslutningen "Jugendwerk «. Den overordnede politiske linje var nazistisk, hvilket bl.a. indebar en fælles ideologisk skoling af alle ungdomsførere.

Leder af ungdomsringen blev skoleleder Carl Tønder, der havde været leder af DJN. I stedet for Reinhold Hesse som leder af ungdomsforbundene trådte skoleleder, senere bibliotekar Peter Callesen til. Callesen tilhørte den moderate fløj af nazister, der ønskede en begrænset ensretning. Dog fandt man i ledelsen også mere rabiate nazister som lærer Asmus Wilhelm Jürgensen, Løgumkloster, der under pseudonymet "Asmus von der Heide« skrev i bl.a. Nordschleswigsche Zeitung og Junge Front. Fælles for Tønder og Jürgensen var en stærk nazistisk pionerånd, hvor målet var effektivt og hurtigt at gennemføre et ensrettet nazistisk ungdomsarbejde.

Uoverensstemmelserne mellem Tønder og Callesen om den politiske linje i 
ungdomsarbejdet fortsatte indtil 1937. Ungdomsforbundene eksisterede indtil 1939, og de fortsatte arbejdet med landsbyungdommen, men fra 1937 havde de reelt udspillet deres rolle som forening for de tysksindede unge.

\section{Deutsche Jungenschaft og Deutsche Mädchenschaft Nordschleswig}

Men hvad var de for nogle størrelser, disse to nazistiske ungdomsorganisationer, der dukkede op i hhv. 1933 og 1934? Hvorledes adskilte de sig fra de rigstyske ungdomsorganisationer, Hitler-Jugend og Bund Deutscher Mädel, som var deres forbilleder, og hvad vil det sige, at organisationerne var nazistiske? Og hvordan lykkedes det for de to nazistiske ungdomsorganisationer at få så stor og bred tilslutning?

For at lette overblikket har jeg inddelt DJN og DMN's historie i to faser: Første fase fra 1933 til 1940 var præget af opbygning, dvs. grundlæggelse af lokale afdelinger, "Standorte«, begyndende førerskoling og indførslen af et ensartet arbejde. Fra 1937 voksede medlemsantallet for alvor, arbejdet i de lokale afdelinger blev udvidet, og de to tidsskrifter "Junge Front " og "Junger Wille« så dagens lys. Dertil kom, at der i ledelsen endelig blev skabt enighed om Jens Møller som partifører for NSDAP-N. Dermed blev DJN og DMN's langvarige politiske neutralitet, dvs. deres neutrale holdning til magtkampen $\mathrm{i}$ Nazi-partiet, brudt.

Anden fase fra 1940 til 1945 var præget af 2. Verdenskrig og den deraf følgende tyske besættelse af Danmark. Efterhånden som krigen skred frem, opstod der et større og større tysk behov for soldater, som man bl.a. søgte at dække ved rekruttering af folketyske frivillige. For Jungenschafts vedkommende betød det, at hovedparten af dets aktiviteter blev rettet mod hvervning af frivillige.

Før 1933 fandtes der så godt som ingen nazistiske grupperinger blandt de tysksindede i Nordslesvig, men dette skulle hurtigt ændre sig efter Hitlers magtovertagelse $\mathrm{i}$ januar 1933. Allerede $\mathrm{i}$ april samme år havde de tyske ungdomsorganisationer bekendt sig til den nazistiske udvikling $i$ et "Manifest der deutschen Jugend ${ }^{6}{ }^{6}$ Heri proklameredes løftet om at være med til at opbygge nationalsocialismen i Nordslesvig med ordene: "Vi lover med alle kræfter at arbejde for den nationale og socialistiske opbygning af det nye rige i Nordslesvig «. ${ }^{7}$ Det organiserede ungdomsarbejde kom dog først i gang senere samme år med grundlæggelsen af "Deutsche Jungenschaft Nordschleswig“ $i$ forbindelse med den årlige tysk-nationale sportsfest på Knivsbjerg. Her var 300 af deltagerne med til at stifte den nye nazistiske ungdomsorganisation. 


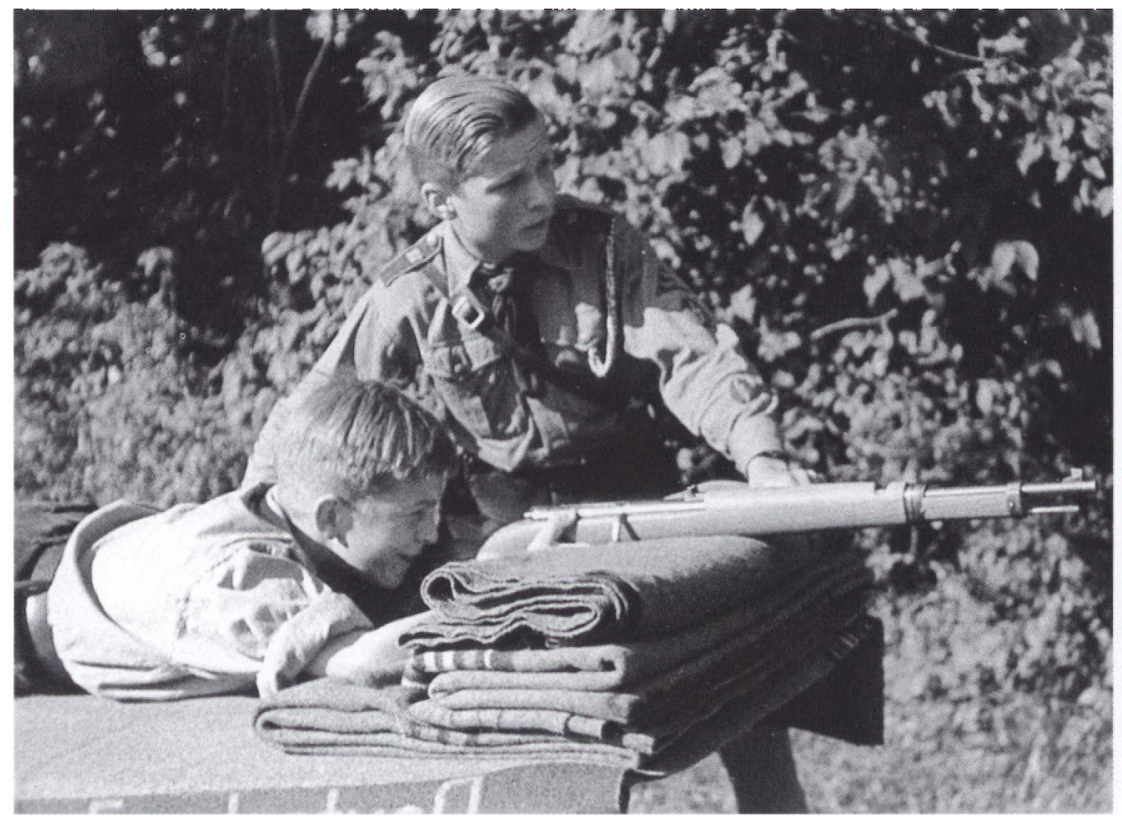

Efterligning af militare ovelser var et vigtigt led $i$ den militare opdragelse, som her hvor unge drenge fra Tyskland 1943 over sig $i$ at skyde med luftgevar. Udover skydning var terransport og marcher et fast programpunkt i DJN's arbejde. Terransport var en form for militare ovelser, hvor det gjaldt om at erobre land og bekampe fjenden.

Søsterorganisationen "Deutsche Mädchenschaft Nordschleswig" blev grundlagt omkring et år senere, i maj 1934. I det foregående år havde kvinderne deltaget på lige fod med mændene i Jungenschafts arrangementer og rejser. Mädchenschafts grundlæggelse betød, at man nu fik den kønsadskillelse, som var det nazistiske ideal. En "førerinde « fandt man dog først i 1935 i Christine Jakobsen, hvis far havde været aktiv i mindretallets første nazistiske organisation Nationalsozialistische Arbeitsgemeinschaft Nordschleswig (NSAN), som blev oprettet $\mathrm{i}$ april 1933. I løbet af dette ene år havde Mädchenschaft fået mellem 800 og 900 medlemmer. Denne hastige vækst i medlemmer viste, at det nazistiske ungdomsarbejde hurtigt fik tag i kvinderne.

Holdningen bag de nye organisationer var entydig: Det tyske mindretals nazistiske organisationer skulle i størst muligt omfang ligne de rigstyske forbilleder. Dette blev besluttet på et møde i januar 1934 mellem repræsentanter fra vigtige tyske ministerier og organisationer og en rakke ledende tysksindede grænsepolitikere. ${ }^{8}$ Men for ikke at belaste forholdet til Danmark skulle organisationerne udadtil fremtræde som selvstændige nordslesvigske organisationer.

På den anden side var det ikke bare af navn, at DJN og DMN adskilte sig 
fra hhv. HJ og BDM. Meget tyder på, at de nordslesvigske organisatorer bestræbte sig på en stor grad af selvstændighed. Dette markerede sig bl.a. ved, at man kun i meget begrænset omfang samarbejdede med søskendeorganisationerne i Slesvig-Holsten. I arkiverne er der heller intet, der tyder på, at DJN og DMN fik dikteret deres politik fra Berlin.

\section{Organisationsstruktur i DJN/DMN}

I tråd med den generelle efterligning af rigstyske nazistiske organisationer blev også DJN og DMN opbygget efter HJ og BDM's struktur, dog i en forenklet udgave. I stedet for en rigsungdomsledelse (Reichsjugendführung) var der en landsungdomsledelse (Landesjugendführung). Landsungdomsledelsen var den øverste ledelse for DJN/DMN og senerehen for det samlede tyske ungdomsarbejde. Føreren for drengeorganisationen DJN blev kaldt Landesführer (landsfører), og den kvindelige leder blev benævnt Landesmädelführerin (landsførerinde). Landsføreren var tillige leder af hele ungdomsarbejdet og havde så i denne funktion titlen Landesjugendführer. Landsungdomsledelsen repræsenterede et distrikt, som i størrelse omtrent svarede til, hvad man i Tyskland kaldte et »Bann«. I Tyskland var der i alt 223 Banne.

Mens de tyske "Banne « havde endnu et par niveauer over sig, var det nordslesvigske "Bann« direkte underlagt rigsungdomsledelsen i Berlin. Rigsungdomsledelsen i Berlin var dog ikke det vigtigste tyske styringsorgan for DJN/ DMN. Volksdeutsche Mittelstelle, som var et SS-ledet organ til koordinering af mindretalsarbejdet, havde langt større indirekte indflydelse gennem tildelingen af økonomiske midler til det tyske kulturarbejde i Nordslesvig. I løbet af fire år, fra juli 1941 til maj 1945, fik mindretallet som helhed tilført i alt 7 mio. kroner. Det tyske skolevæsen fik langt størstedelen af pengene, mens Jungenschaft fik $88.000 \mathrm{kr}$. og Mädchenschaft $0.52 .000 \mathrm{kr}$. $^{9}$

Mens der i Hitler-Jugend og BDM var tale om en underopdeling efter alder (10-14 år: Jungvolk, 14-18 år Hitler Jugend) gjorde dette sig ikke i samme grad gældende for Nordslesvig. DJN og DMN optog medlemmer helt ned til 8-års alderen. Det gjorde man ikke i Tyskland, hvor aldersgrænsen var 10 år. Den øverste aldersgrænse i DJN/DMN var 18 år, men også efter denne grænse kunne de unge fortsætte i systemet som førere og førerinder for hhv. DJN og DMN.

Endelig havde landsungdomsføreren under sig en række afdelinger, som f.eks. "Schulungsamt", som stod for ideologisk skoling, et "Presseamt", som bl.a. udgav tidsskrifterne Junge Front og Junger Wille. Denne inddeling gjaldt også DMN.

For begge organisationer var forholdet til nazipartiet af betydning. Den interne strid i mindretallets ledelse fra 1933 til henimod 1938 holdt de to organisationer sig helt udenfor. 


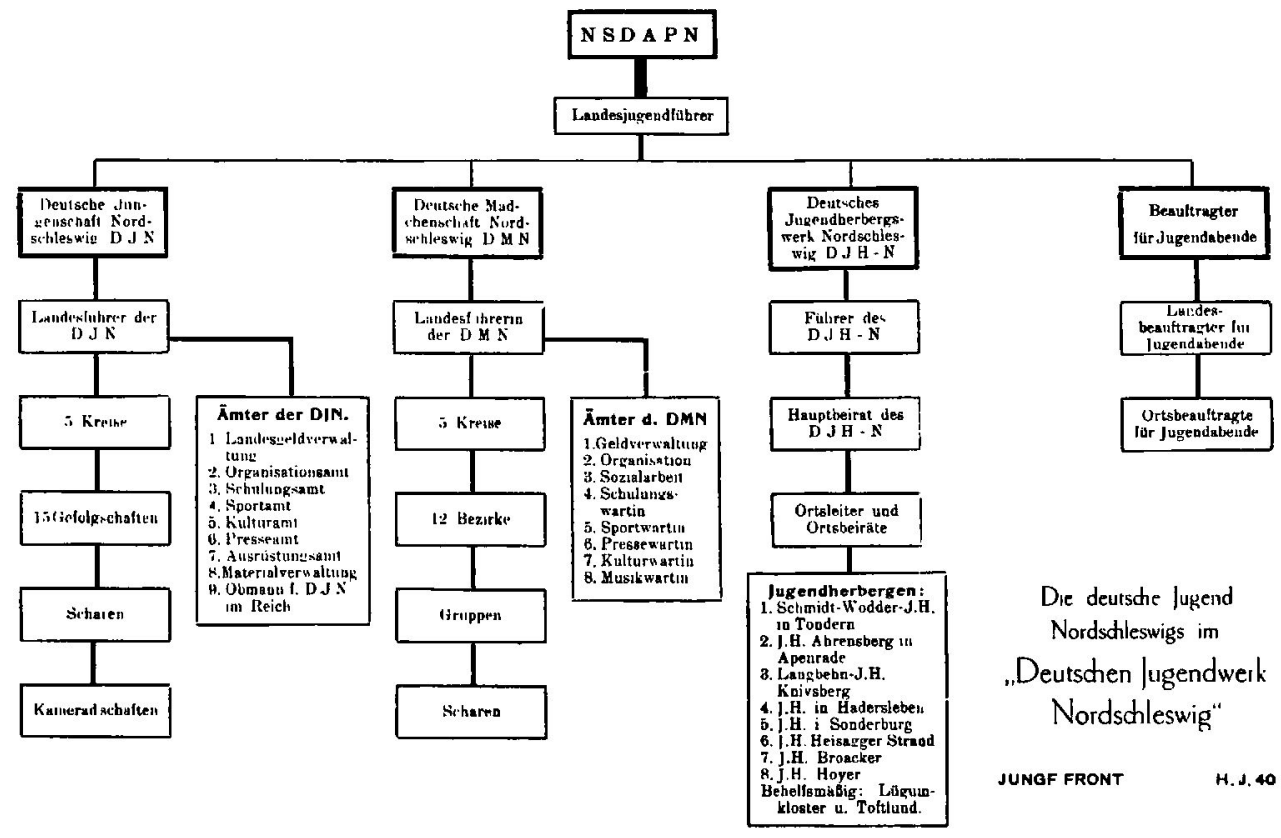

Oversigt over det tysksindede ungdomsarbejde 1940. Hele ungdomsarbejdet var formelt underlagt nazipartiet, men i praksis synes der ikke at have varet problemer med denne lagdeling. Den overste leder af ungdomsarbejdet (Landesjugendführer) og den overste leder af drengearbejdet (Landesführer der DJN) var altid en og samme person. Landsungdomsforeren havde udover Jungen- og Mädchenschaft ogsd vandrerhjemsarbejdet og »den ansvarlige for ungdomsaftenere under sig. Sidstnavnte begreber var en rest af det ikke-nazistiske ungdomsarbejde for 1933. Til Jungenschaft og Madchenschaft var der tilknyttet en rakke mindre enheder, "Ämter", som eksempelvis stod for skoling. (dvs. ideologi), sport eller kultur. Kredsen var de storste enheder i DJN og "Kameradschaften " de mindste. Gengivet efter Junge Front 1940.

Så længe striden varede, blev DJN/DMN holdt uden for NSDAP-N's indflydelse. Men derefter blev de to nazistiske ungdomsorganisationer tættere tilknyttet partiet som en del af partiapparatet. Fra 1941 fik DJN/DMN status som organisation under partiet (»Gliederung der Partei« i modsatning til de løsere tilknyttede forbund, »angeschlossene Verbände (). Det betød, at partiføreren nu blev stillet over de to organisationer og fik ret til at gribe ind i deres anliggender. Frem til 1944 gjorde partilederen Jens Møller imidlertid ikke brug af denne mulighed. Forholdet mellem partiføreren og landsungdomsføreren i disse år, Jef Blume, var efter alt at dømme godt. Møller interesserede sig for ungdomsarbejdet og deltog gerne i møder og arrangementer.

Efter Blumes afgang blev forholdet mellem ungdomsorganisation og moderparti dog et andet. Især hvervningen af frivillige henimod krigens slutning fremkaldte en del uoverensstemmelser mellem Jef Blumes efterfølger og Møller. 


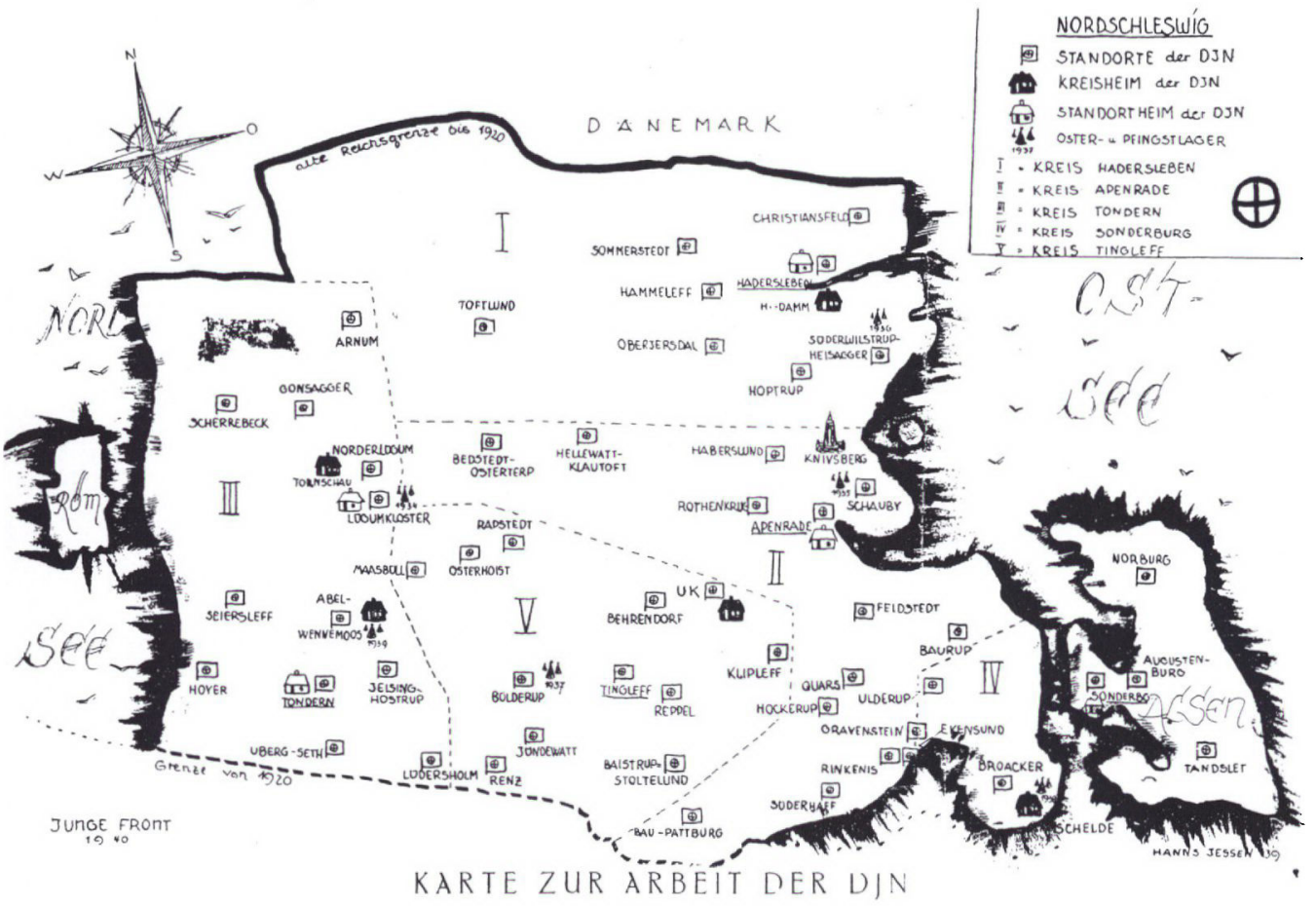

Ungdomsarbejdet i Nordslesvig var inddelt i fem kredse. "Standort" var den lokule afdeling inden for DJN og blev betragtet som kernen i DJN's arbejde. Markeringerne "Kreisheim" og "Standortheim" viser tilholdsstederne for DJN. Nogle af disse hjem havde Jungenschaftlerne selv bygget. Lag i ovrigt marke til markeringerne af den dansk-tyske granse og Kongeảgransen. Gengivet efter Junge Front 1940.

Ungdomsorganisationernes integration i NSDAP-N betød også, at landsungdomsføreren fik sæde i det såkaldte "Lille politiske Råd«, som blev oprettet i 1941 til drøftelse af mindretallets politiske arbejde. I rådet sad repræsentanter fra de vigtigste organisationer i mindretallet og de fem kredsledere fra NSDAP-N. Rådet fik afgørende politisk betydning, idet alle vigtige beslutninger blev drøftet og truffet her.

At ungdommen fik plads $\mathrm{i}$ rådet skal ses på baggrund af hvervearbejdet for tysk krigstjeneste. Den mandlige tyske mindretalsungdom fik nemlig storre og storre betydning i kraft af rekrutteringerne til Waffen-SS.

\section{Arbejdsprogrammet $1933-40$}

I de forste år efter oprettelsen prægedes arbejdet i Jungenschaft og Mädchenschaft af en generel udbygning af organisationen, herunder grundlæggelsen af lokale afdelinger. Uddannelse af førere og opbygningen af et ensartet arbejde 
var de vigtigste stikord. Ved udbyggelsen af DJN og DMN prioriterede man arbejdet $\mathrm{i}$ de lokale afdelinger højst, næst efter uddannelsen af førere. Disse lokalafdelinger blev anset for Jungen- og Mädchenschafts kerne. Derfor blev der lagt særlig vægt på, at dette arbejde fungerede, for wher bliver arbejdet med den enkelte dreng fuldbyrdet, her bliver kammeratskabet til, som bærer den store helhed og fører fremad «. $^{10}$

Lokalafdelingernes vigtigste aktivitet var den ugentlige hjemaften (Heimabend), hvor sang, nazistisk ideologi og leg stod på dagsordenen.

Førerne af de forskellige lokalafdelinger blev samlet til førerskoling en gang om ugen, hvor der blev givet retningslinjer for det praktiske arbejde. Derudover blev der afholdt nogle skolingstræf i 1934 med terrænsport, dvs. halvmilitære øvelser. Terrænsport kunne dog kun i begrænset omfang udføres på grund af de danske myndigheders forbud mod militærlignende øvelser. Temaerne udvidedes det følgende år til at omfatte forskellige former for idræt såsom redskabsgymnastik, fægtning og boksning.

For Mädchenschafts vedkommende bestod arbejdet primært af hjemaftenen, sociale arrangementer og opdragelse til huslige sysler. En af deres bibeskæftigelser var desuden at servicere Jungenschaft, når de skulle bespises $i$ forbindelse med lejrture og lignende.

Jungenschaft blev fra 1933 ramt af den danske regerings uniformsforbud. Dertil kom, at der skulle søges tilladelse til at afholde marcher og brænde bål. Ved DJN's marcher måtte der ikke spilles tyske national- og kampmelodier, og ved march gennem byer måtte der ikke synges fællessang overhovedet. ${ }^{11}$ DJN's nazistiske fane var ligeledes bandlyst. DJN fulgte reglerne, men var stærkt utilfreds med politimyndighedernes behandling af Jungenschaft. Man mente, at Jungenschaft burde behandles som en almindelig dansk idrætsorganisation. Begræsningerne med hensyn til offentlig fremtræden gjaldt ligeledes Mädchenschaft.

\section{Påske- og pinselejre og Knivsbjergfest}

Det første store arrangement, der blev gennemført, var påskelejren, som fandt sted i 1934 i Løgumkloster. Dette arrangement blev gentaget i de følgende år, og det blev den vigtigste årlige begivenhed for Jungenschaftlerne. 1934-lejrens program er skildret i Deutscher Volkskalender. Det giver et indtryk af disse arrangementers karakter:

Fra de forskellige lokalafdelinger vandrede drengene med fakler i en såkaldt stjernefart til Løgumkloster, hvor en tysk landmand havde stillet sine marker til rådighed. Der deltog 300 drenge i 10-18 årsalderen. Derudover deltog 50 rigstyske drenge. Påskelejren (som senere blev til en pinselejr) blev det vigtigste og det største arrangement for Jungenschaft med 0.500 deltagere de følgende 


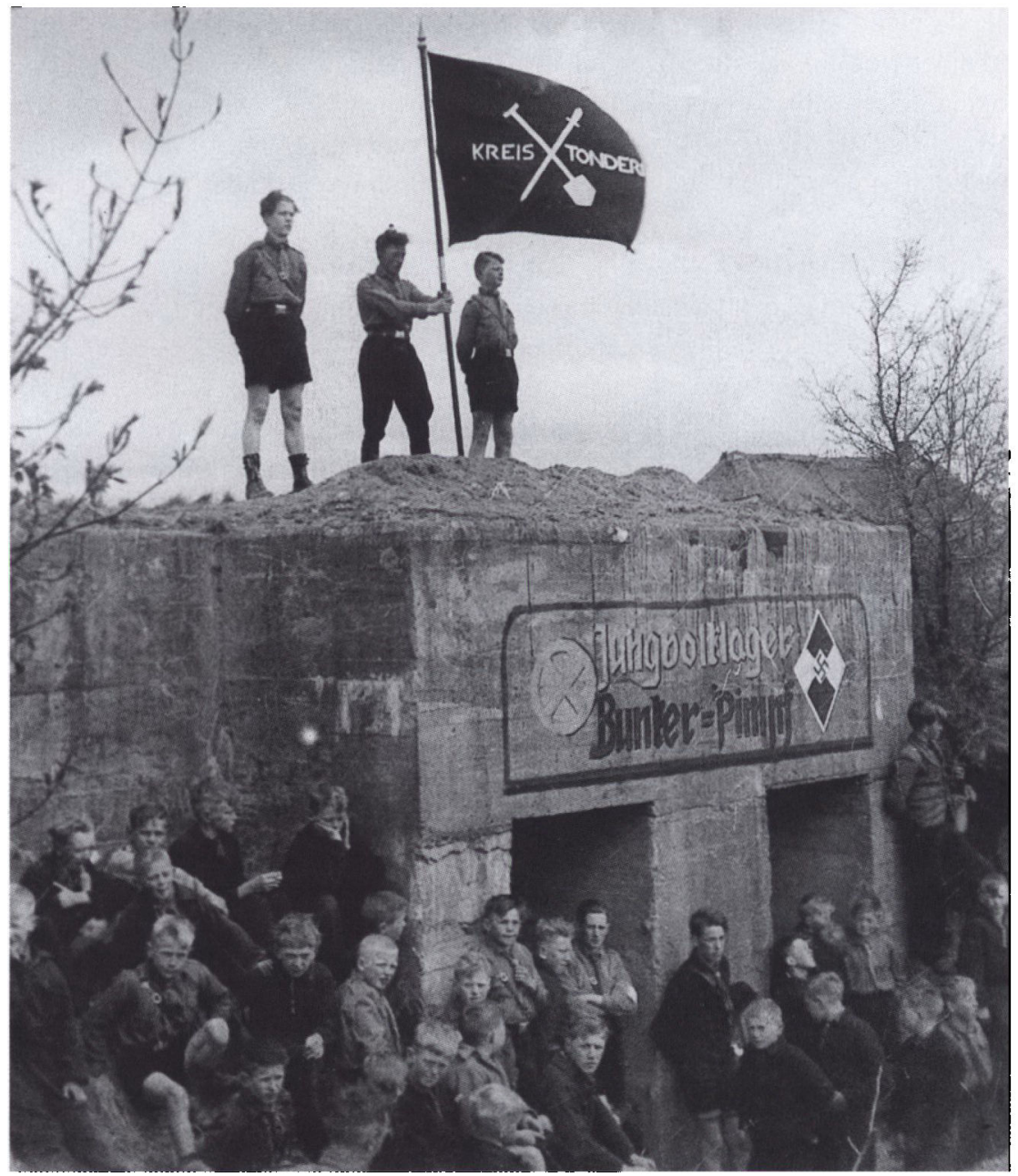

Lejrene var en vigtig del af Jungen-og Madchenschafts virke. Udover pdskelejren, som var den vigtigste, var der f.eks. forerlejre, lejre for de yngre og aldre medlemmer, musiklejre, lejre for unge bonder. Billedet her er fra en "Jungvolklager", dvs. for de 9-14-årige. Lag marke til DJN's kredsflag, der har spaden og svardet som symboler.

år. I de følgende år afholdtes lejrene hos forskellige landmænd i Sønderjylland med deltagelse af rigstyskere og tyskere fra andre mindretal (folketyskere). Mädchenschaft var involveret i påskelejren ved at lave mad. I påskelejren forenedes de discipliner, som DJN dyrkede i det daglige: Ideologi, terrænsport og almindelig sport.

Lejrens program var bygget op efter militært forbillede. Dagen startede med 
At hejse fanen var et fast programpunkt ved enhver lejr, som her hvor to unge Mädchenschaftlere heiler under den nazistiske fane $p d ̊$ en "Jungmädelführerinnenlagerw $i$ Skelde $i 1943$.

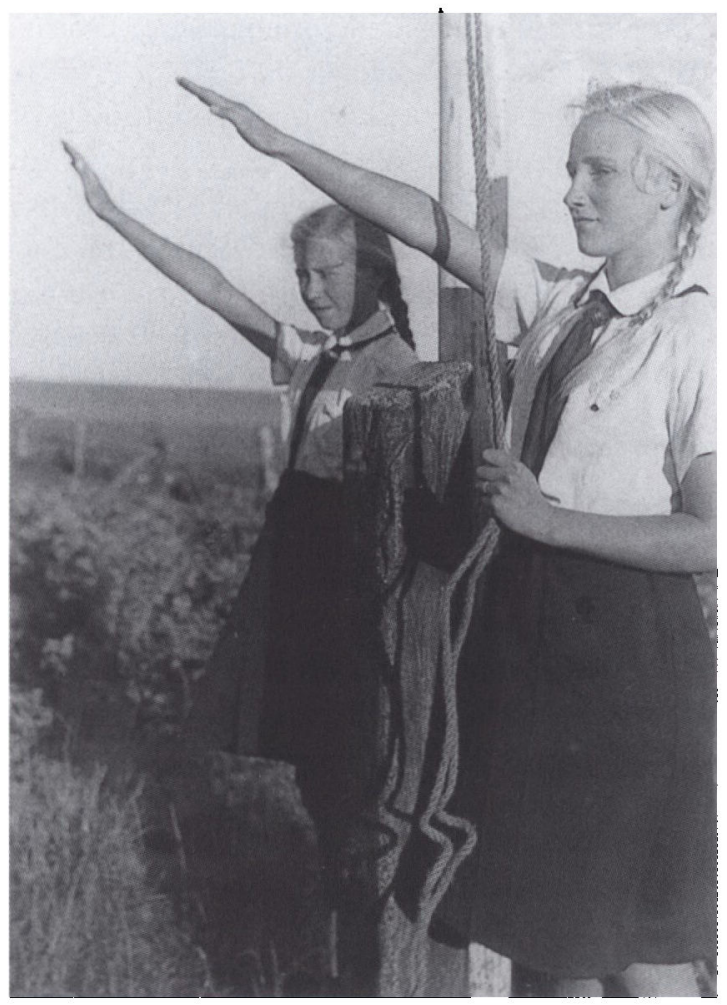

morgensport, appel og flaghejsning. Efter morgenmaden var der typisk forberedelse til idrætsmærket (Das Deutsche Jungenschaft-Leistungsabzeichen), eller der blev arrangeret terrænøvelser. Om aftenen kunne der være filmforevisning. I 1937 blev filmene »Das Auslandsdeutschtum« og »Das Leben und Treiben im Nordmarklager« vist, og der blev afholdt hjemaften. Som ved en rigtig soldaterlejr blev der holdt vagt døgnet rundt. Et fast element i påskelejren var et stort påskebål og en march gennem en nærliggende by. Påskelejren indeholdt også et "Thing der Jungenschaft«, hvor det kommende års arbejde blev fremlagt.

At det ikke var alle, der var positivt stemte over for påskelejren fremgår af en artikel i DJN's blad Junger Wille fra $1937 .{ }^{12}$ Heri pointeredes vigtigheden af at tage med på påskelejren under overskriften: »Hvorfor tage med på Jungenschafts påskelejr? «. ${ }^{13}$ Den dreng, der ikke ville deltage i lejren, blev betragtet som svag og egoistisk: "Svarer han [drengen] Nej, jeg bliver hjemme, så er det et tegn på manglende kraft til at sejre over sig selv i fællesskabets interesse«. Hvis han derimod marcherede med, ville han blive en del af det kammeratskab, 
hvor pligt, tjeneste og underordning stod i centrum, og hvor fysiske anstrengelser skulle virke hærdende på sjælen.

Artiklen afsluttes med følgende opfordring til forældre, der stadigvæk havde betænkeligheder: "Den [påskelejren] har opdraget os og vil komme til at opdrage mange drenge. Det er en stor opgave, hvis opfyldelse mange forældre fra begyndelsen har arbejdet for, og som alle forældre skal arbejde for!«.

En anden vigtig begivenhed var den årlige Knivsbjerg-fest. Denne fest var ingen nazistisk opfindelse, den havde tværtimod eksisteret siden 1894 som modstykke til de danske møder på Skamlingsbanken. Ved de første fester deltog DJN og DMN sammen med de tyske ungdomsforbund, men senerehen optrådte de alene med deres egne indslag, "Kundgebungen«. Til disse fester var der altid stor tilslutning, i 1934 og 1935 deltog omkring 1.000 Jungen- og Mädchenschaftler. ${ }^{14}$

Derudover var der arrangementer som cykel- og vandreture og udflugter i Nordslesvig og til Tyskland. Dette var altsammen ting, der skulle gøre DJN og DMN mere attraktive for børnene og de unge fra mindretallet.

\section{Jef Blume}

Den mand, der om nogen kom til at tegne det tyske ungdomsarbejde i perioden fra 1937 til 1944 var Jef Bertelsen Blume. Forgængeren Carl Tønder havde valgt at lægge sine kræfter $i$ ensretningen af ungdomsarbejdet, og Jef Blume havde udmærket sig som en god organisator i Tønder-kredsen, som han havde overtaget i 1935. Tønder-kredsen var vanskelig i den henseende, at Wandervogel-bevægelsen her stod stærkt. Ideologisk havde Blume sit bagland i orden: Han havde tidligt bekendt sig som nazist og havde været med til at grundlægge en "Ortsgruppe« af det nazistiske elevforbund (Nationalsozialistischer Schülerbund) på gymnasiet i Niebüll som 16-årig i 1930. Efter studentereksamen i 1933 uddannede han sig til lærer i Kiel og vendte tilbage til Nordslesvig, til Sæd, hvor han blev lærer på den tyske kommuneskole. Det var derfor ikke overraskende, at der netop blev peget på ham som efterfølger for Carl Tønder.

I slutningen af 1937 overtog han posten som landsungdomsfører. Blume opnåede først og fremmest at medlemstallet steg. Landsungdomsledelsen blev organisatorisk udvidet, antallet af arrangementer voksede og førerskolingen fik mere organiserede rammer. Fra 1942 fik Junge Front desuden større betydning som mindretallets officielle presseorgan. I Blumes tid som leder startede hvervningerne til Waffen-SS.

Af særlige aktioner i årene fra 1934 til 1940 kan bl.a. nævnes den store aktion for at skaffe hjem, "Heime«, til DJN og DMN's aktiviteter. Aktionen tog fart fra omkring 1938 og gav gode resultater. For 1938 havde man haft to bygninger til de lokale afdelinger (Standort-Heime). I 1940 havde DJN og 


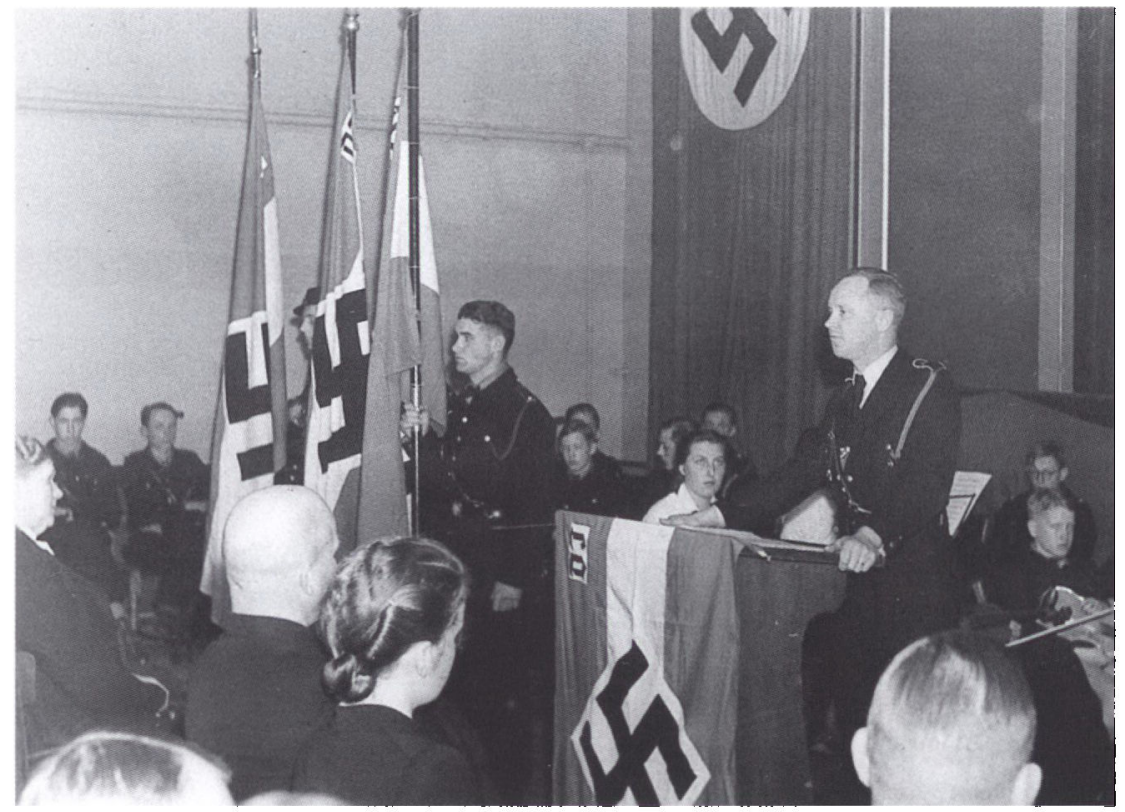

Lederen af den tyske ungdom. landsungdomsforer Jef Blume (1912-1996) ger status for det foregdende ar ved et forermode for DJN og DMN i Ahenra 7. april 1944. Jef Blume blev leder af det tyske ungdomsarbejde i 1937. I foräret 1944 tog han sin afsked for at gore krigstjeneste i Waffen-SS. Under hans ledelse udbyggedes Jungen- og Mädchenschaft til to effektive ungdomsorganisationer, der $i 1944$ havde nasten 3.300 medlemmer. Dette svarede efter mindretallets egne beregninger til en organiseringsgrad på ca. $95^{\prime \prime}$ ".

DMN fem kredsbygninger og fem Standortbygninger til alle større Standorte og endelig en Gefolgschaftsbygning. ${ }^{15}$

\section{Hverning af medlemmer}

DJN og DMN's medlemstal voksede eksplosivt mellem 1933 og 1940, fra 300 til 2.650 medlemmer. Det var især mellem 1937 og 1939, at tilgangen var størst: For Jungenschafts vedkommende steg medlemstallet fra 880 til 1.250. For Mädchenschaft var tilgangen noget mindre, nemlig fra 1.100 til 1.370.

Men hvordan lykkedes det DJN og DMN at få så mange nye medlemmer? Tvang kunne jo ikke komme på tale på samme måde som i Tyskland, hvor det blev obligatorisk at være medlem af de nazistiske ungdomsorganisationer i december 1936.

Hvervningen foregik på flere måder: For det første gennem medlemmerne selv, dvs. gennem anbefaling af DJN og DMN til kammerater. For det andet 


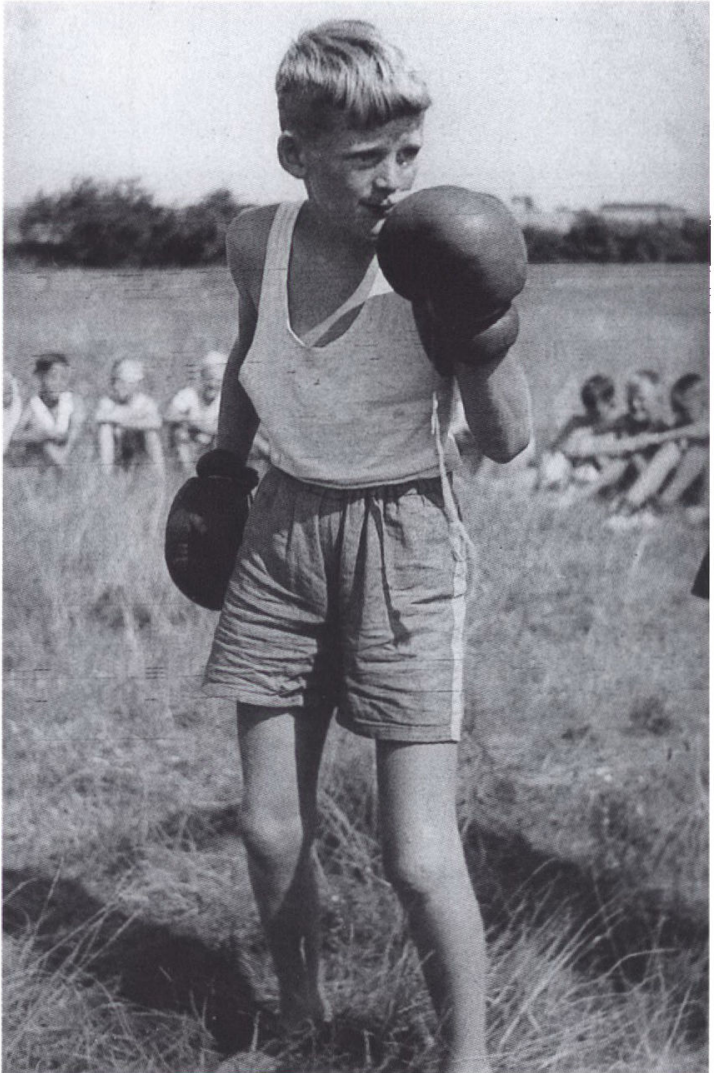

Hitler betragtede de sportslige udfoldelser som langt vigtigere end den boglige lardom. Derfor horte de sportslige aktiviteter til det allervigtigste arbejdsomrade for DJN og DMN. Idrat blev dyrket $p d$ de utallige lejre, ved udflugter, dagsmarcher og ved atletikkonkurrencer. Konkurrenceformen var her et vigtigt element $i$ afprovningen of de sportslige fardigheder. Boksning var i ovrigt Hitlers yndlingssport. Her en ung bokser pd Pimpfenlager der DJN ved Hejsager 1943.

reklamerede lederne for tjenesten i DJN eller DMN, og endelig hvervede man medlemmer gennem tilbagevendende stort anlagte forårskampagner.

Hvad den mundtlige hverning angår, spillede de tyske institutioner, særligt den tyske skole, en altdominerende rolle. Mange af førerne og førerinderne havde tilknytning til tysk skole eller børnehave, enten som lærere, børnehavelærerinder, eller som pårørende til lærere. På de tyske privatskoler var dobbeltrollen som lærer og fører særlig udpræget. En dag for en tysk lærer kunne f.eks. være almindelig undervisning om formiddagen, en udflugt om eftermiddagen og gennemforelse af en hjemaften om aftenen. Denne dobbeltrolle kunne med hensyn til tiltaleform volde børnene problemer: I skolen skulle man tiltale læreren med "De«, mens man ved DJN og DMN's arrangementer skulle tiltale læreren med »du«. Bag den afslappede tiltaleform i DJN og DMN lå forestillingen om, at alle generationsmæssige og sociale forskelle var ophævet i det nazistiske fallesskab. 
Endelig havde dobbeltrollen den effekt, at lærerne stod som garanter for ungdomsarbejdets kvalitet. I Junger Wille fra januar 1938 gives der et indblik i lærernes rolle som hververe. En pige, J., beretter om, hvordan hun blev medlem af Mädchenschaft. Faderen var ikke begejstret for hendes ønske og mente, at det var nok at være medlem af Jugendbund. Hvortil hun svarer: "Jamen, dette er så vigtigt, dér skal man være med!« - og fortsætter: »Har du ikke hørt, hvad BDM i Tyskland udretter?«. Dette argument afviser faderen og henviser til, at Nordslesvig ikke er Tyskland. Pigen lader sig ikke affærdige; "Men vi forsøger jo at gøre det ligesom tyskerne i riget. « Intet synes at hjælpe, indtil skolelæreren dukker op i hjemmet og lægger et godt ord ind hos faderen. Så får hun endelig lov til at blive medlem.

Det var essentielt for DJN og DMN at have et godt omdømme blandt forældrene, idet det var dem, der i sidste ende afgjorde, om barnet fik lov til at være med eller ej. Forældrenes accept var således altafgørende for DJN og DMN. Som følge heraf var hvervekampagnerne i lige så høj grad rettet mod forældre som mod børn. Disse tillidsskabende kampagner syntes at være faldet i god jord blandt forældrene. I hvert fald erindrer Jef Blume, ${ }^{16}$ at forældreopbakningen var stor. Han mindes ikke at have hørt om forældre, der var imod Jungen- eller Mädchenschaft, selv ikke blandt de familier, om hvem man vidste, at de ikke var nazistiske. Også deres børn var medlemmer af Jungenschaft eller Mädchenschaft.

Jeg har dog i Jungenschafts arkiv fundet én sag, hvor en dreng af forældrene bliver udmeldt af DJN. Først er der et brev fra faderen (på tysk), hvoraf det fremgår, at hans søn ikke kan betragtes som medlem af Jungenschaft, fordi faderen ikke kan få hjælp [NJ: sandsynligvis til gården]. Senere hen har moderen skrevet et brev til skolen: "I går eftermiddag har De sikkert ventet V. men han er meget ked af deltage $\mathrm{i}$ den Jungenschaft, så hvis det ingen tvang er ligesom skolen, håber jeg han må være fri«. Og hun slutter med de fortvivlede ord: "I det hele taget kan det aldrig blive som det skal være, når den ene af forældrene er tysk, den anden dansk, men er der noget at endre når det ligger et slægtled tilbage ${ }^{17}{ }^{17}$ Dette brev giver et udmærket billede af det dilemma, som mange blandede familier i Nordslesvig stod i.

Udover hvervningen fra mund-til-mund var der særlige hverveaftener og en årlig stor kampagne mellem 10. februar og 14. marts, som var de to datoer for folkeafstemningen i $1920 \mathrm{i}$ hhv. 1. og 2. zone. Disse store kampagner vil jeg kort kaste et nærmere blik på, fordi de giver et indtryk af hvervekampagnernes stil og retorik.

Den første egentlig hvervekampagne blev gennemført i 1938. Hvervekampagnen blev annonceret i Junge Front. Et nummer af Junger Wille blev udgivet som et specielt hvervenummer. Selve bladet indeholdt opfordringer fra lands- 


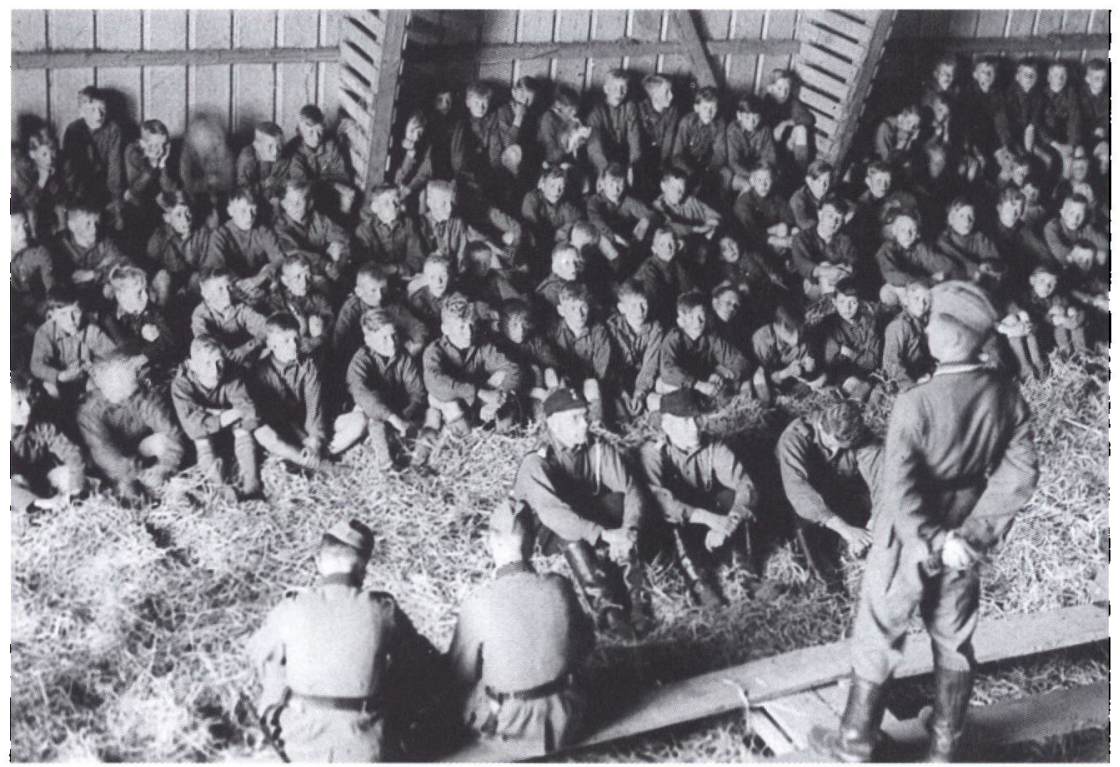

Opdragelsen til soldat var det vigtigste led i den nazistiske ideologi. At blive soldat var det hojeste og fornemste hverv for en tysk mand i Det tredje Rige. I Jungenschaft lagde man tilsvarende hovedvagten af aktiviteterne på den militure opdragelse. Målet for Jungenschaft var, at enhver ty'sksindet dreng, der fyldte 18, skulle melde sig til tysk krigstjeneste. Derved ville han pătage sig den samme forpligtelse, som en dreng $i$ Tyskland var nodt til at opfylde. Her fortceller en frontsoldat om tilvarelsen ved fromten pd en forerlejr for DJN ved Sogard i 1944.

føreren i DJN og landsførerinden i DMN. Jungenschaftler og Mädchenschaftler fortalte om tjenesten, om lejrophold, ture til Tyskland, og om at have set føreren til et møde i Kiel.

Men hvorfor brugte man så mange ressourcer på de grandiose hvervekampagner, når hvervningen umiddelbart syntes at fungere udmærket gennem de mundtlige kanaler? Det er der flere grunde til: Hovedmålet var naturligvis at få alle tysksindede unge organiseret $\mathrm{i}$ hhv. DJN og DMN. I foråret 1941 regnede mindretallet selv med, at omkring $90 \%$ af mindretallets unge var organiseret $\mathrm{i}$ Jungenschaft og Mädchenschaft. ${ }^{18}$ Men man ville gerne have fat i de sidste procenter, som samtidig var de sværeste, idet disse »blakkede « enten forsøgte at holde sig uden for en entydig national stillingtagen eller måske allerede havde taget stilling til fordel for den danske side. Forældre, som var imod, blev opfordret til at lade børnene blive indlemmet $i$ »den tyske ungdoms store enhed «: »Giv dem muligheden for at opfylde deres tjeneste i den nye tids marchskridt", hed det $\mathrm{i}$ januar 1938 i Junger Wille. ${ }^{19}$ E. F. beretter stolt i samme nummer, at det $i$ hans kreds er lykkedes at få samtlige tyske skoledrenge til at blive medlem af DJN. 
Hvervekampagnerne opfyldte også et andet vigtigt formål: De samlede medlemmerne $i$ et fællesskab om at opnå nogle konkrete mål, som alle kunne være enige om. At hverve nye medlemmer var en opgave, som kunne forene på tværs af de sociale og kulturelle forskelle inden for mindretallet, som stadigvæk fandtes, selvom nazismen hævdede det modsatte.

Selve hvervekampagnen, som varede en hel måned, foregik så godt som alle steder i Sønderjylland, hvor der var tysksindede. DJN og DMN samarbejdede om disse kampagner. Der var hverveaftener, hvor alle forældre, bekendte og venner var inviteret til at overvære, hvordan DJN og DMN's arbejde foregik. På hverveaftenerne var der sang, måske et teaterstykke og fortællinger fra tjenesten i DJN og DMN.

Groft sagt var der tale om et politisk teater, som udover at forene de tyske unge $i$ et fællesskab også var en manifestation af en enig ungdom over for de dansksindede. Et ikke uvelkomment trak ved kampagnerne var desuden, at de unge Jungen- og Mädchenschaftler fik lejlighed til at møde hinanden, da disse var nogle af de få fællesaktiviteter i den ellers kønsopdelte ungdomsbevægelse.

Kampagnerne blev en stor succes: I 1938 deltog flertallet af Mädchenschaftlerne i hverveaktionen (1.157), og der kom 4.785 gæster. Hvor mange nye medlemmer, der kom, er lidt mere uvist. DJN fik den største fremgang med 266 nye medlemmer til i alt 1.146 . I 1940 kom der 100 nye til. Formodentlig har tallet hos Mädchenschaft været nogenlunde det samme, men det fremgår ikke præcist, hvor mange nye medlemmer, der kom til.

Som tidligere nævnt benyttedes i hvervekampagnerne en meget svulstig retorik: "De svæklinge og stympere, som alligevel stiller sig udenfor, foragter vi og anser for at være de sørgelige rester fra en svunden tid, som i det hele taget ikke mere hører hjemme i vor verden ... Vil du, kammerat, da hjælpe til og kæmpe med. Vi kræver din klare stillingtagen. Vort løsen er: Kun den der stormer, har ret til at leve«.20

Men hvordan har Mädchen- og Jungenschaftlerne selv opfattet disse hvervekampagner? Har de følt det som en tvang, eller er de gået frivilligt ind i de nazistiske ungdomsorganisationer? Forfatteren Manfred Spliedt, der som 1216-årig var med i Jungenschaft, husker, at det var mskolens gruppenormer, der krævede at man blev medlem «. ${ }^{21}$ Når alle kammeraterne fra ens klasse var med i Jungen- og Mädchenschaft, så ville man ikke stå udenfor. To af de interviewede fremhæuede medlemsskabet af DJN/DMN som en naturlig følge af, at Jugendbünde ikke eksisterede længere. ${ }^{22} \mathrm{DJN}$ og DMN var den eneste mulighed for at blive organiseret $i$ en ungdomsorganisation. For andre var det de forlokkende toner om det frie liv i naturen, der trak. ${ }^{23}$ For mange har det formodentlig været en kombination af flere motiver. 
De tidligere Jungen- og Mädchenschaftler påpeger alle senerehen, at det var frivilligt at være med, og at ingen fører havde absolut magt over én. Rudolf Andresen nævner i sine erindringer fra Haderslev et eksempel på en dreng, der ikke gad vælte rundt i det våde græs og lege soldat. Da troede alle, at det var forbi med ham, men føreren gjorde ingenting; han kunne ingenting gøre. ${ }^{24} \mathrm{Om}$ Andresens erindringer på dette punkt er alment galdende, kan nok diskuteres. Der har nok også været andre lokalafdelinger, hvor føreren forholdt sig anderledes.

\section{Arbejdsprogrammet $1940-45$}

1940 har jeg sat som skæringspunkt for begyndelsen af anden fase, fordi Danmark den 9. april 1940 blev besat af Tyskland. For mindretallet skabte besættelsen forventninger om en snarlig genindlemmelse af Nordslesvig, hvilket også smittede af på DJN og DMN. Årene 1940/41 markerede et sidste fremstød for at få fat $\mathrm{i}$ de »blakkede«. Dette var især tilfældet på skoleområdet, hvor tyskere, der havde »skiftet side«, blev opfordret til at sende deres børn i tyske skoler. ${ }^{25}$

Jungenschaft fik især fra 1942 at mærke, at førerne meldte sig frivilligt til Waffen-SS. Alligevel lykkedes det i mange tilfælde at opretholde det samme aktivitetsniveau som før krigen. At dømme efter erindringer fra tidligere medlemmer synes tjenesten $\mathrm{i}$ Jungenschaft at være blevet strengere og mere kedelig, ${ }^{26}$ men tjenesten var dog også kendetegnet af, at der kom nye opgaver til: Jungen- og Mädchenschaft iværksatte et samarbejde med de tyske tropper $i$ Danmark. Bl.a. afholdt Mädchenschaft forskellige arrangementer for tyske soldater. Arbejdet i Jungen- og Mädchenschaft fortsatte, indtil de allersidste måneder før krigens afslutning.

I Jungenschaft blev arbejdet anført af den højtdekorerede Johann Thorius, der havde afløst Jef Blume som landsungdomsfører. Thorius iværksatte den allersidste hverveaktion til Waffen-SS i februar måned $1945 .{ }^{27}$

Det er således karakteristisk, at der var en gruppe inden for Jungenschaftlerne, der til det allersidste aktivt kæmpede for den nationalsocialistiske sag. Det ser man også i det sidste nummer af Junge Front, der udkom i april 1945. Det sluttede med disse ord, dateret den 20. april, som var Hitlers fødselsdag: "Den tyske folkegruppe er naturligvis ikke uberørt af udviklingen, men den lader sig ikke ryste i sin tro på den klare tyske ret og vore fjenders uret. Derfor fejrer Schmidt-Wodder sin førers fødselsdag med den samme tilslutning og troskab, som i alle de foregående år«. Underskrevet af Amt für Presse und Propaganda. 


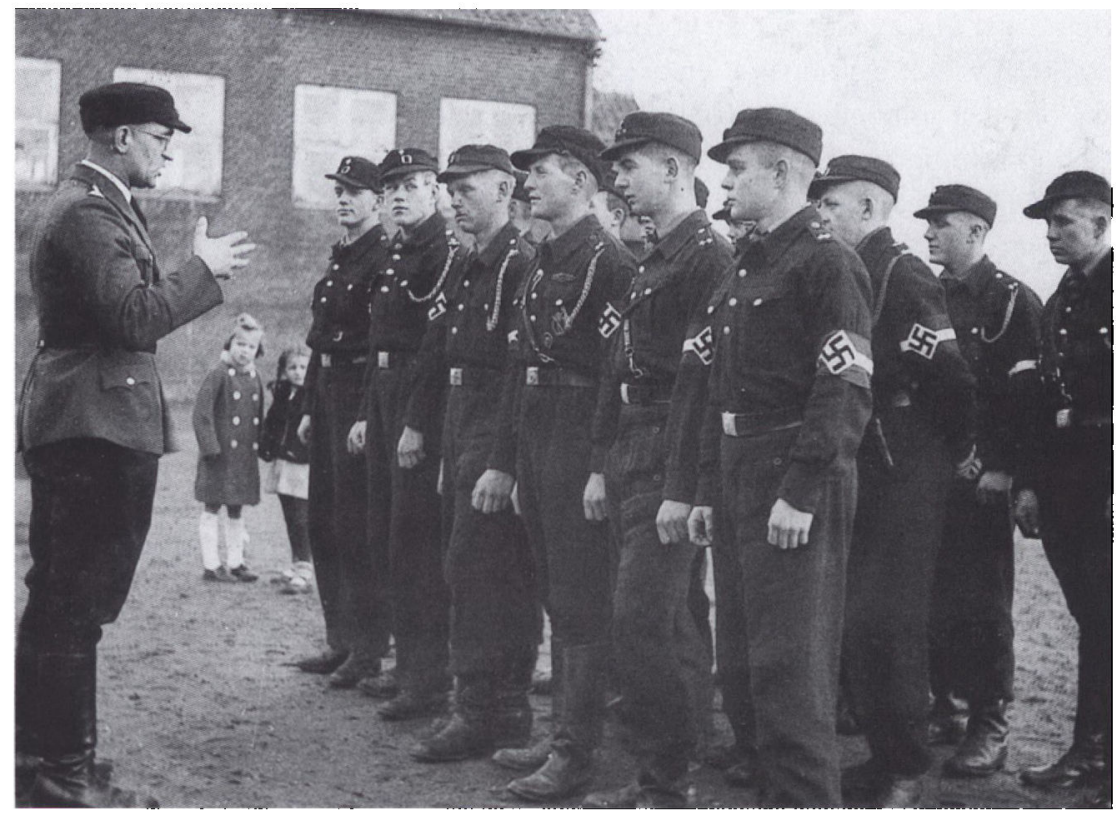

Larer og kredsleder i DJN Bruno Thaysen blev midlertidig indsat som landsungdomsforer $i$ 1944, indtil den hojt dekorerede SS-Obersturmführer Johann Thorius i januar 1945 overtog posten. Her beder Thaysen i dec. 1944 underforerne om at styrke indsatsen i de lokale afdelinger. Arbejdet i Jungenschaft led starkt under mandskabsmangel, da mange forere var ved fronten.

\section{Jungenschaftler i tysk krigstjeneste}

Opdragelsen til soldat var kernen i den nazististiske drengeopdragelse. Hele træningen hos DJN var lagt an på at gå i krig for Tyskland. Det blev for mange DJN-førere derfor en naturlig opfølgning at gå i tysk krigstjeneste. Udover førerne, som var over 18, kunne unge mænd allerede gå ind $\mathrm{i}$ WaffenSS fra 17-års alderen. I alt stod i 1944 omkring $1.800^{28}$ medlemmer af mindretallet i tysk krigstjeneste, heraf var 285 DJN-førere. Derimod er det svært at afgøre, hvor mange menige og tidligere Jungenschaftler, der $i$ alt deltog $i$ krigen.

Hvor vigtig en opgave hvervningen af frivillige og selve krigstjenesten var for DJN, fremgår bl.a. af, at Junger Wille fra oktober 1942 blev til en feltavis for frivillige ved fronten. Tidsskriftet indeholdt derefter billeder af faldne fra DJN, udmærkelser og forfremmelser, breve fra Jungenschaftler i felten og endelig en beretning fra arbejdet $i$ folkegruppen af Gefolgschaftsführer Wilhelm Jürgensen (Asmus von der Heide). Junger Wille vedblev dog samtidig at være medlemsblad for DJN.

I Junger Wille og i Junge Front blev det gang på gang understreget, hvor 
vigtigt det var at kæmpe, at tjene det tyske folk og at underordne sig fællesskabet. Et godt eksempel er en artikel af Fridrich Harr fra Junge Front: Tanker om den militære opdragelse af vort unge mandskab (Gedanken über die Wehrerziehung unsrer jungen Mannschaft): "Den kommende tid vil stille os over for opgaver, der er større, end vi nogensinde har set før, som vi kun kan løse $\mathrm{i}$ et fællesskab, som ikke kender jeg'et, men kun vi'et, og i hvilket alle ivrigt og uden tøven gør deres pligt i frivillig disciplin og underordning, kort og godt: når vi har viljen til at tage en hård militær opdragelse på os«. Han fortsætter endvidere, at den tyske folkegruppe er sikret en plads i tusindårsriget. Det kræver imidlertid, at folkegruppen er villig til at arbejde for det, og han konstaterer: "Vi kan dog kun gøre dette, når vi er tapre og jernhårde.» Folkegruppen skal følge Frederik den Stores valgsprog: "Jeg tjener." Han slutter med en opfordring til dem, der endnu står udenfor, om at slutte sig til de marcherendes rækker: "Også dig har vi brug for! «. ${ }^{29}$

Udover at være et forsvar for den militære opdragelse er indlægget således også en opfordring til de unge mænd i mindretallet om at melde sig frivilligt til tysk krigstjeneste. Det blev betragtet som en naturlig pligt for den unge mand at melde sig. Jef Blume udtrykte det i sin årsberetning for Jungenschaft fra 1944 på denne måde: "Det er helt klart, at vi som tidligere har det mål foran os, at enhver dreng, som er blevet 18 , melder sig frivilligt som soldat, og dermed frivilligt påtager sig det, som bliver forlangt af enhver dreng i Riget «., ${ }^{30}$

Efter krigens afslutning blev alle tidligere frivillige $i$ tysk krigstjeneste retsforfulgt. Man kunne måske tro, at domsudskrifterne ville være en kilde til Jungenschaftlernes krigsindsats. Men domsudskrifterne indeholder kun sporadisk oplysninger om medlemsskab af Jungenschaft.

Derimod findes der i Deutscher Volkskalender Nordschleswig opgørelser over Jungenschafts indsats. Disse opgørelser registrerer dog kun en del af de Jungenschaftler, der var med i krigen. Oversigten dækker kun de DJN-førere, der var med i SS og værnemagten, og ikke de menige og de tidligere medlemmer af DJN. ${ }^{31}$

\begin{tabular}{lll}
\hline & DJN-forere & Faldne \\
\hline 1940 & & 3 \\
1941 & ingen oplysninger & \\
1942 & 180 & 21 \\
1943 & 241 & 35 \\
1944 & 285 & 62 \\
1945 & ingen oplysninger & \\
\hline
\end{tabular}

Set i forhold til hele folkegruppen, hvis krigsindsats i Waffen-SS og værnemagten pr. 3. juni 1944 som nævnt udgjorde mindst $1.800,{ }^{32}$ var DJN-førernes andel på ca. 15\%. Tabstallet var af lignende størrelse. 
Tysk gravsten fra Rusland. Omkring 2.100 meldre sig til $y$ sk krigstjeneste fra det tyske mindretal i Danmark. langt storstedelen til Waffen-SS. Der eksisterer ikke precise tal for Jungenschaftlernes samlede indsats $i$ tysk krigstjeneste. I 1944 opgjorde man dog antallet af $D J N-f o-$ rere i tyske enheder til omkring 280.

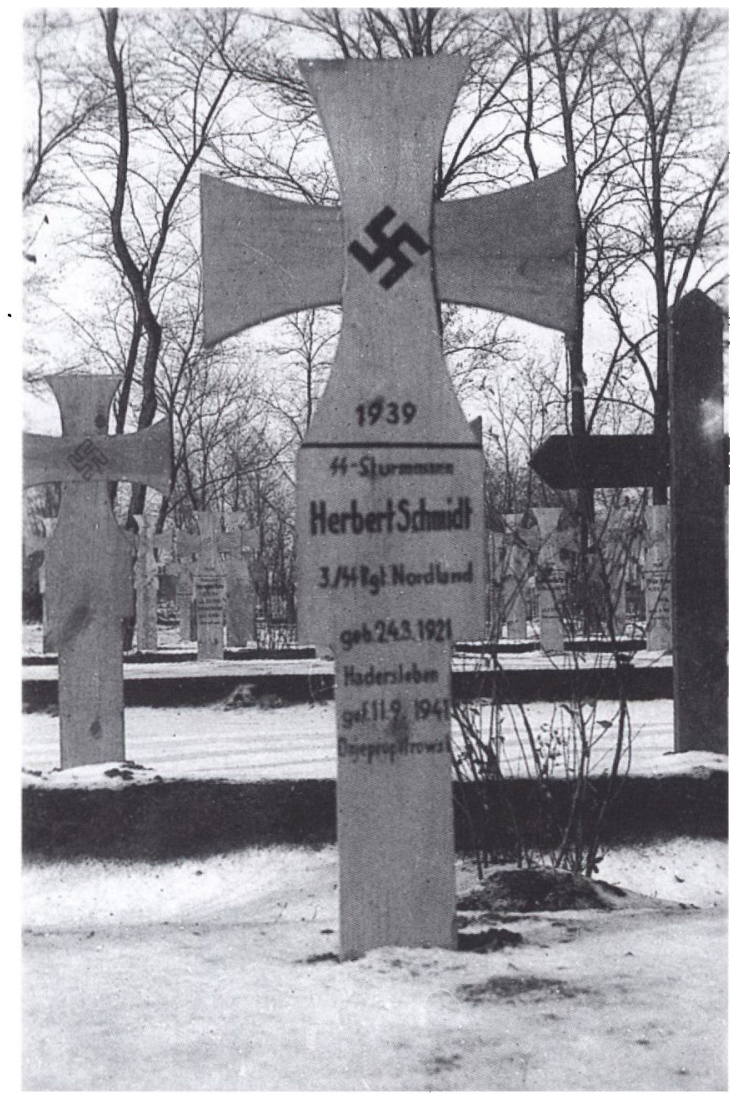

I løbet af krigen steg antallet af DJN-førere i krigstjeneste markant i forhold til det samlede antal frivillige fra mindretallet. ${ }^{33}$ Størstedelen af tilgangen skyldtes, at lærere, der tidligere var blevet erklæret for uundværlige for hjemstavnen, nu blev indkaldt.

De fleste af DJN-førerne gjorde tjeneste $\mathrm{i}$ Waffen-SS, en mindre del var $\mathrm{i}$ enten luftvåbenet, marinen eller den almindelige hær. De fleste af de faldne faldt på østfronten, hovedsageligt i Rusland, men der var også enkelte tab på vestfronten. Folketyskerne kom gennemgående i de samme SS-enheder. Det drejede sig om divisionerne Wiking, Das Reich, Nordland og Totenkopf-Standarte. Ud af de 62 førere, der faldt, var eksempelvis 13 i SS - Panzerdivision Totenkopf..$^{34}$

Et ukendt antal Mädchenschaftler gjorde tjeneste som såkaldte frontsøstre, dvs. som sygeplejersker i SS-lazaretter. Det samlede antal danske statsborgere, som udøvede denne gerning, anslås til ca. $60 .^{35}$ 
Et dxkkende tal for antallet af Jungenschaftler i tysk krigstjeneste findes som nævnt ikke. Derfor kan man ikke sige noget sikkert om udviklingen $i$ hvervningen i løbet af krigen. Men vi ved, at selve indkaldelserne især i starten ramte den yngste del af de tjenesteduelige - dem uden forpligtelser. Derfor må vi antage, at andelen af Jungenschaftler - både tidligere aktive, menige medlemmer og førere - var forholdsvis stor. Samtidig ved vi, at presset på mindretallets unge i den tjenesteduelige alder blev større og større, efterhånden som krigen skred frem.

\section{Konklusion}

Også i Nordslesvig fik den nazistiske bevægelse i Tyskland afgørende betydning. Der blev dannet nye nazistiske ungdomsorganisationer, og de allerede eksisterende ungdomsforbund måtte erkende, at det var disse nye organisationer, som havde overherredømmet. Derefter sygnede de gamle hurtigt hen. Nazificeringen af det tyske ungdomsarbejde lykkedes, selv om der ikke stod egentlige tvangsmidler til rådighed. Dette ensretningsarbejde gav Jungen- og Mädchenschaft monopol på den tysksindede ungdom.

De to foreninger var i hovedtræk identiske med deres tyske forbilleder. Dette gjaldt med hensyn til organisationsstruktur, indhold og form. De adskilte sig først og fremmest ved en større grad af autonomi $i$ forhold til de centrale myndigheder i Berlin. Man kopierede formen, men beholdt en begrænset selvstændighed. I dag kan man ikke se tegn på at Berlin ville styre ungdomsorganisationerne, men dette skal nok ses som et udtryk for, at det tyske ungdomsarbejde i Nordslesvig holdt sig inden for de uskrevne rammer, som samarbejdet med Berlin satte. Disse rammer var ikke mindst en følge af, at Berlin stod for tildelingen af de økonomiske midler til Jungenog Mädchenschaft.

Flere af de tidligere Mädchenschaftler fremforte senere, at de to ungdomsorganisationer i deres væsen svarede til spejderbevægelsen blot med tysk fortegn. Sådan kan man sagtens have opfattet det dengang. Mange af aktiviteterne kan genfindes hos spejderbevægelsen. På det overordnede plan medførte de forskellige elementer af nazistisk ideologi og skoling imidlertid, at de to organisationer blev væsensforskellige fra f.eks. spejderbevægelsen. Opdragelsen til at følge de nazistiske idealer førte for en del direkte til Østfronten. 


\section{UTRYKTE KILDER}

\section{Landsarkivet for Sønderjylland}

Deutsche Jungenschaft Nordschleswig nr. 769-791.

Deutsche Madchenschaft Nordschleswig nr. 798-818.

\section{Privateje}

Uddrag af Jef Blumes erindringer.

\section{Interviews}

Manfred Spliedt, Birkerød: 20.3.1995.

Adeline Hauschildt, Jejsing: 4.4.1995.

Heie Ratenburg og Hanni Brendel, Tønder: 6.4.1995.

Jef Blume, Nørre Løgum: 6.4.1995

\section{NOTER OG HENVISNINGER}

1. Citeret fra Henrik Becker-Christensen: Det tyske mindretal i Nordslesvig 1920-1932, 1990, Bd. I, s. 251 efter "Grenzland Schleswig«, s. 106-107.

2. Henrik Becker-Christensen: Det tyske mindretal i Nordslesvig 1920-1932, 1990, bd. I, s. 252253.

3. Deutscher Volkskalender für Nordschleswig 1926, s.36.

4. Brockhaus Enzyklopädie, 19. Auflage, Bd. 8, 1989, s. 583 "Gleichschaltung«.

5. Deutscher Volkskalender Nordschleswig 1935, s.114-115.

6. "Nordschleswigsche Zeitung«, 10. april 1933.

7. "Wir geloben, mit allen Kräften an dem nationalen und sozialistischen Aufbau des neuen Reiches in Nordschleswig mitzuarbeiten «.

8. Sven Tägil: Deutschland und die deutsche Minderheit in Nordschleswig. Eine Studie zur deutschen Grenzpolitik, Stockholm, 1973, s. 54.

9. Bilag til Beretning til Den Parlamentariske Kommission, XIV, bd. 1 nr. 211. s. 284.

10. ")Hier wird die Arbeit an dem einzelnen Jungen vollzogen, hier bildet sich die Kameradschaft, die wieder das große Ganze trägt und vorwărts bringt«. DJN-Jahresbericht i Deutscher Volkskalender Nordschleswig 1936, s. 103.

11. Jungenschafts arkiv 782: Tilladelse fra politimesteren $\mathrm{i}$ Tonder til march $\mathrm{i}$ forbindelse med påskelejr, 24.3.1937. J - Nr. M 44/37.

12. Junger Wille, Sonderbeilage, påsken 1937 , s. 2. Jungenschafts arkiv 786.

13. Was soll das Osterlager der Jungenschaft? "Antwortet er [drengen] nein, ich bleibe zu Haus, so ist das ein Zeichen für mangelnde Kraft, über sich selbst im Interesse der Gemeinschaft zu siegen«.

14. Deutscher Volkskalender Nordschleswig 1935, s. 103 og 1936, s. 102.

15. En blanding af nazistiske, slesvig-holstenske og andre helte lagde navn til hjemmene: HerbertNorkus-Heim i Ảbenrå (en heltefigur for Hitler-Jugend), Manfred-von-Richthofen-Heim ved Uge (Den røde Baron) Max-Valentiner-Heim (en lokal helt der var tysk ubådskommandant) og endelig Uwe Jens Lornsen.

16. Interview med Nina Jacobsen.

17. Jungenschafts arkiv 773 .

18. Den parlamentariske Kommissions beretning, Bilag, XIV bd. 2, 1953, Det tyske konsulat til gesandtskabet i København om den tyske folkegruppes virksomhed, 3. febr. 1941 (nr. 70) og Uddrag af den tyske folkegruppes månedsberetning for marts 1941 (nr. 71).

19. Junger Wille, januar 1938, s. 2.

20. Junger Wille, januar 1938, s. 4. 
21. Manfred Spliedt: Sådan en dum knægt, 1975, s. 23.

22. Rudolf Andresen: Jungenschaftsjahre in Hadersleben, i: Deutscher Volkskalender Nordschleswig, 1995, s. 48. Adeline Hauschildt, interview.

23. Spliedt: Sådan en dum knægt s. 23.

24. Rudolf Andresen: Jungenschaftsjahre in Hadersleben. Deutscher Volkskalender Nordschleswig 1995 s. 52.

25. Den parlamentariske Kommissions beretning, XIV bd. 2, dokumenter nr. 202-10, Overflytning af rigstyske børn fra danske til tyske skoler.

26. "Strengere« ifolge interview med Hauschildt (der refererer sin bror) og mere kedelig. se Rudolf Andresen: Jungenschaftsjahre in Hadersleben s. 57. Se endvidere Manfred Spliedt: Sádan en dum knægt s. 67.

27. Se nærmere herom i Bilag til Beretning til Den Parlamentariske Kommission XIV,2 nr. 337-340 om de sidste hvervekampagner. Se desuden s. S4ff i min oprindelige prisopgave "Tysk ungdomsarbejde i Nordslesvig 1933-1945«, som denne artikel bygger på (eksemplar i Landsarkivet i Aabenraa).

28. Den parlamentariske Kommissions beretning, Bilag, XIV,2 nr. 330.

29. Junge Front, november 1940, s. 4.

30. Jef Blume, erindringer i privateje (status over Jungenschafts arbejde 1933-1944).

31. Volkskalender 1941, 1942, 1943, 1944 og 1945. Tallene for 1943 og 1944 er opgjort pr. 1.10.

32. Parl. Komm. XIV,2. nr. 330.

33. Fra juni 1943 til januar 1945 steg antallet af frivillige med 140, hvoraf mindst 44 var DJN-forere.

34. Medlemmerne af Totenkopf-Standarte kan identificeres ud fra kravemærkerne på billederne af de faldne i Junger Wille.

35. Oluf Krabbe: Danske soldater i kamp på østfronten. Odense 1976, s. 32. 